Article

\title{
Antimicrobial Properties, Cytotoxic Effects, and Fatty Acids Composition of Vegetable Oils from Purslane, Linseed, Luffa, and Pumpkin Seeds
}

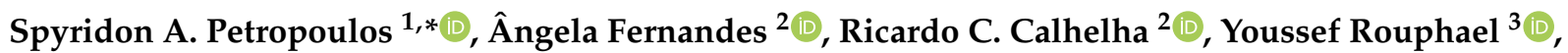
Jovana Petrović ${ }^{4}$, Marina Soković ${ }^{4}$, Isabel C. F. R. Ferreira ${ }^{2} \mathbb{C}$ and Lillian Barros ${ }^{2, *} \mathbb{E}$

check for

updates

Citation: Petropoulos, S.A.;

Fernandes, Â.; Calhelha, R.C.;

Rouphael, Y.; Petrović, J.; Soković, M.;

Ferreira, I.C.F.R.; Barros, L.

Antimicrobial Properties, Cytotoxic

Effects, and Fatty Acids Composition

of Vegetable Oils from Purslane,

Linseed, Luffa, and Pumpkin Seeds.

Appl. Sci. 2021, 11, 5738. https://

doi.org/10.3390/app11125738

Academic Editors:

Gwiazdowska Daniela, Krzysztof Juś and Katarzyna Marchwińska

Received: 15 May 2021

Accepted: 18 June 2021

Published: 21 June 2021

Publisher's Note: MDPI stays neutral with regard to jurisdictional claims in published maps and institutional affiliations.

Copyright: (c) 2021 by the authors. Licensee MDPI, Basel, Switzerland. This article is an open access article distributed under the terms and conditions of the Creative Commons Attribution (CC BY) license (https:/ / creativecommons.org/licenses/by/ $4.0 /)$.
1 Laboratory of Vegetable Production, Department of Agriculture, Crop Production and Rural Environment, University of Thessaly, Fytokou Street, N. Ionia, 38446 Volos, Greece

2 Centro de Investigação de Montanha (CIMO), Instituto Politécnico de Bragança, Campus de Santa Apolónia, 5300-253 Bragança, Portugal; afeitor@ipb.pt (Â.F.); calhelha@ipb.pt (R.C.C.); iferreira@ipb.pt (I.C.F.R.F.)

3 Department of Agricultural Sciences, University of Naples Federico II, Via Universita 100, 80055 Portici, Italy; youssef.rouphael@unina.it

4 Institute for Biological Research "Siniša Stanković" - National Institute of Republic of Serbia, University of Belgrade, Bulevar Despota Stefana 142, 11000 Belgrade, Serbia; jovana0303@ibiss.bg.ac.rs (J.P.); mris@ibiss.bg.ac.rs (M.S.)

* Correspondence: spetropoulos@uth.gr (S.A.P.); lillian@ipb.pt (L.B.); Tel.: +30-242-109-3196 (S.A.P.); +351-273-330-901 (L.B.)

Featured Application: Vegetable oils are a rich source of fatty acids and bioactive compounds with numerous beneficial effects to human health. The presented results showed that seed oils of linseed, purslane, luffa, and pumpkin have significant antimicrobial properties that could find application in the food industry as functional ingredients or as non-synthetic antimicrobial agents in the design of new healthy food products. Moreover, they could be used in mixtures with other oils to design new vegetable oils with functional properties and enhance content in omega-3 fatty acids.

Abstract: In the present study, the antimicrobial and cytotoxic activities, as well as the fatty acids composition in vegetable seed oils from linseed, purslane, luffa, and pumpkin were evaluated. For this purpose, two linseed oils and one luffa oil were commercially obtained, while purslane and pumpkin oils were obtained from own cultivated seeds. The results showed a variable fatty acids composition among the tested oils, with $\alpha$-linolenic, linoleic, oleic, palmitic, and stearic acid being the most abundant compounds. In regards to particular oils, linseed oils were a rich source of $\alpha$-linolenic acid, luffa and pumpkin oil were abundant in linoleic acid, while purslane oil presented a balanced composition with an almost similar amount of both fatty acids. Luffa oil was the most effective against two of the tested cancer cell lines, namely HeLa (cervical carcinoma) and NCI-H460 (non-small cell lung cancer), while it also showed moderate toxicity against non-tumor cells (PLP2 cell line). Regarding the antibacterial activity, linseed oil 3 and pumpkin oil showed the highest activity against most of the tested bacteria (especially against Enterobacter cloacae and Escherichia coli) with MIC and MBC values similar to the used positive controls (E211 and E224). All the tested oils showed significant antifungal activities, especially luffa and pumpkin oil, and for most of the tested fungi they were more effective than the positive controls, as for example in the case of Aspergillus versicolor, A. niger, and Penicillium verrucosum var. cyclopium. In conclusion, the results of our study showed promising antimicrobial and cytotoxic properties for the studied seed oils which could be partly attributed to their fatty acids composition, especially the long-chain ones with 12-18 carbons.

Keywords: seed oils; antibacterial properties; cytotoxicity; antifungal properties; omega-3 fatty acids; omega-6 fatty acids; antitumor activities; Portulaca oleracea L.; Luffa aegyptica Mill.; Cucurbita maxima L.; Linum usitatissimum L. 


\section{Introduction}

The food industry is looking for novel natural compounds to be used as non-synthetic antimicrobial agents in the whole food chain, aiming to fulfill consumers demands for healthy and chemical-free food products [1]. The concept of bio-preservation through the use of plant derived antimicrobial agents is of major importance for food safety and food security, while providing additional functional properties to food products at the same time [2]. For this reason, the research interest has focused on various plant species also considering obtaining novel compounds from the by-products of food processing industries [3]. In this context, lipids and oils are a promising source of antimicrobial agents since according to the literature they have been found to possess such activities $[4,5]$. Especially for seed oils and extracts, there are several examples of significant in vitro antimicrobial effects against food-borne pathogens for seed oils of conventional and unconventional crops that could found in applications in the food industry $[2,6]$.

Vegetable oils are considered a basic ingredient in many dietary patterns, such as the Mediterranean diet, and provide essential nutrients and valuable bioactive compounds with beneficial health effects [7]. They are considered rich sources in sterols, polyunsaturated fatty acids (PUFA), polyphenols, and carotenoids, although there could be significant differences in oil composition depending on the extraction method e.g., cold or thermal pressing, use of solvents, supercritical extraction, etc. [8]. The most common oils around the world are obtained from palm, soybean, rapeseed, and sunflower, being used for culinary purposes in raw form or after processing for the production of hydrogenated oil with further uses in the food industry, as well as in industrial applications in cosmeceuticals, paint industry, or biofuel production [9].

Apart from the well-known and widely used vegetable oils, there are several minor seed oils which possess special features related to their chemical composition and bioactive properties $[10,11]$. Their unique characteristics are usually related with fatty acids composition, especially omega-3 fatty acids content [12,13], or specific bioactive compounds such as polyphenols or tocopherols that contribute to the observed antioxidant and bioactive properties [14,15]. However, despite their beneficial effects, most of these oils are underexploited since either they used for industrial applications with low added value or they considered as byproducts because plants are cultivated for vegetative tissues and harvested before entering the reproductive stage e.g., fibers in the case of flaxseed [16]. During the last years, scientific research has indicated various species as rich sources of beneficial fatty acids, some of which are currently being used in the food and pharmaceutical industry [17]. For example, vegetable oils from species such as sacha inchi (Plukenetia volubilis), linseed (Linum usitatissimum), and perilla (Perilla frutescens) are rich in $\alpha$-linolenic acid and monounsaturated fatty acids (MUFA), whereas chia (Salvia hispanica) and purslane (Portulaca oleracea) contain $\alpha$-linolenic and linoleic acid (LA) in amounts that account to omega-6/omega-3 ratios with values lower than 4 , indicating high nutritional value [17-19].

Flax or linseed (Linum usitatissimum L.) can be cultivated for its seeds and in this case it is named after the terms "linseed", "flax seed", "oil flax", or "seed flax", or it can be cultivated for its fibers and then it is referred to "flax". There are also dual purpose cultivars which can be grown both for fibers and seeds [20]. The seed oil can be used for non-edible industrial applications as a drying oil or for edible purposes due to its high content in omega-3 $\alpha$-linolenic acid [20]. Due to susceptibility to lipid oxidation, it has been suggested that edible linseed oil could be encapsulated or supplemented with powders of edible flowers that increased oxidative stability and improved the quality parameters of oil [20]. Moreover, encapsulated oils broaden the applications in the food industry since they can be incorporated in various food products without altering their physicochemical properties while at the same time they improve their functional properties [21]. The high content of linseed oil in omega-3 fatty acids is also responsible for significant antioxidant, antimicrobial properties and various health effects [22], and according to Wrona et al. [23] linseed oil could be used in active packaging of food products and extend their shelf-life. 
Pumpkin or cucurbit seeds are highly appreciated for their health effects and increasing consumption trends are evidenced during the last few years [24]. Seeds are usually discarded during fruit processing, therefore finding new alternative uses may increase the added value of pumpkin crop in the circular economy context. However, there is a limited cultivation of pumpkins intended for seed production and applications in the food industry as confectionaries or consumed in raw of roasted form [25]. Moreover, seeds can be used for oil extraction which exhibits several beneficial health effects due to their content in bioactive compounds such as fatty acids, tocopherols, and phytosterols (mostly squalene) [26,27]. However, extraction protocols and processing condition, as well as the genotype, may affect bioactive compounds content, and cold-pressing oils are considered of higher quality and nutritional value than thermal- or solvent-processed ones, despite the lower oil yields [28-30]. Moreover, among the various health effects seed oils also possess antimicrobial properties which may find practical application in the food and pharmaceutical industries, since they exhibit significant potency against various microbes [31,32].

On the other hand, purslane is mostly appreciated for its edible leaves and stems which are among the richest plant sources of $\alpha$-linolenic acid [33]. Several health benefits have been attributed to purslane plant parts, including antioxidant, anticancer, hepatoprotective, and antimicrobial properties, among others [34,35]. However, the aerial plant parts may also contain high amounts of oxalic acid which is an antinutritional factor and may have severe effects in individuals with kidney problems [36]. Seeds and seed oils are not so commonly used and recent research highlighted their valuable properties associated with the unique chemical composition, especially the fatty acids profile $[8,10]$, while they do not contain oxalic acid which enables their safe consumption [11,37]. Among the studied species luffa is the least known and is commonly used for its spongy flesh as a natural sponge, while other suggested uses include oil removal from waste water and oil spills [38] and biofuel production [39]. Moreover, luffa seeds are considered a rich source of protein while seeds and seed oil are edible and possess a high nutritional value and bioactive properties [40-42].

Considering the importance of vegetable oils in the human diet and the lack of information regarding less conventional sources of oil, the aim of the present study was to evaluate the fatty acids composition and the antimicrobial and cytotoxic properties of vegetable oils obtained from purslane, pumpkin, luffa, and linseed seeds.

\section{Materials and Methods}

\subsection{Oil Samples}

Oil samples were obtained from seeds of purslane (Portulaca olearacea L.), cucurbit (Cucurbita maxima L. cv. Nychaki), luffa (Luffa aegyptica Mill.) and linseed (Linum usitatissimum L.). In particular, purslane and pumpkin oils were obtained from seeds harvested from plants cultivated at the experimental farm of the University of the Thessaly in the growing period of spring-autumn 2020. Purslane plants were cultivated following the agronomic practices previously described by Petropoulos et al. [11]. In brief, seeds were sown directly in soil on June 12020 and harvested approximately two months later and when most of the plants reached fully maturity (3 August 2020). A base dressing with $100 \mathrm{~kg} / \mathrm{ha}$ of N-P-K was applied, while plants were irrigated via a sprinkler irrigation system at regular intervals. Plant distances were $30 \mathrm{~cm} \times 5 \mathrm{~cm}$, between and within the rows, respectively, while the dimensions of the experimental plots were $3 \mathrm{~m} \times 3 \mathrm{~m}(\mathrm{n}=3)$. No pesticides, fungicides, or herbicides were applied during the growing period, since no certified agrochemicals are available for the species. Weed control was implemented with hand hoeing. Plants were cut at $5-10 \mathrm{~cm}$ above ground with a scythe and seeds were removed from fruit after shaking and sieving. After harvesting, seeds were stored at dry conditions until oil extraction. 
Similarly, pumpkin seeds were sown directly in soil in single rows on 27 July 2020, and fruit was harvested on 7 December 2020. Plant distances were $1.5 \mathrm{~m}$ within each row and $2.5 \mathrm{~m}$ between the rows, while three rows $(\mathrm{n}=3)$ of $50 \mathrm{~m}$ long were used ( 33 plants per row and 100 plants in total). A base dressing with $250 \mathrm{~kg}$ per hectare of 12-11-18 (N-P-K) fertilizer (YaraMila Complex, Yara Hellas S.A., Greece) was applied before sowing, while during the growing period plants were fertigated with ammonium nitrate $(34.5 \%$ nitrogen at $40 \mathrm{~kg}$ per hectare; Idealfer, Gavriel S.A., Greece) and calcium nitrate (15.5-0-0 $+26 \% \mathrm{CaO}$ at $50 \mathrm{~kg}$ per hectare; Haifa-Cal, Haifa Group, Greece). Plants were irrigated via drip irrigation system at regular intervals. Pests and diseases management was carried according to best practice guides, while for weed control mulching with plastic film on sowing lines was applied. After the harvest, fruit were dissected and seeds were removed from the pulp, washed with distilled water, and left to dry at room temperature. After drying, seeds were stored at dry conditions until oil extraction.

Linseed and luffa seed oils were obtained from local retail shops and from GiachanasCold Pressed Seed Oils S.A. (Evros, Greece). In particular, three different samples of linseed and one sample of luffa seed oil were studied, namely linseed oil 1 (Chemco Linseed Oil; Syndesmos S.A., Greece), linseed oil 2 (Giachanas-Cold Pressed Seed Oils S.A.), linseed oil 3 (Organic flaxseed oil; Biotuscany srl., Italy), and luffa seed oil (Giachanas-Cold Pressed Seed Oils S.A.). All commercially available seed oils were extracted via cold pressing, as indicated on the product label.

For purslane and pumpkin seed oils (Purslane oil and Pumpkin oil, respectively), extraction was carried out via cold pressing according to the methodology and the conditions previously described by the authors [10,11]. Both oils were extracted by Giachanas-Cold Pressed Seed Oils S.A., while the cold press was a Henan 6 YL-160 screw oil press (Henan VIC Machinery Co. Ltd.; Henan, China) [11].

After extraction, oils were stored at room temperature at dry and dark conditions in amber screw top glass vials until further analyses.

\subsection{Chromatographic Analysis of Fatty Acids}

Fatty acids were determined by gas-liquid chromatography with flame ionization detection (GC-FID), after the crude fat extraction and derivatization procedures described by Spréa et al. [43]. The analysis was carried out with a DANI model GC 1000 instrument equipped with a split/splitless injector, a FID, and a Macherey-Nagel column. Fatty acid identification was made by comparing the relative retention times of fatty acid methyl ester (FAME) peaks from samples with standards. The results were recorded and processed using the Clarity DataApex 4.0 Software and expressed in relative percentage of each fatty acid.

\subsection{Evaluation of Bioactive Properties in vitro}

\subsubsection{Preparation of Oil Extracts}

The oils ( $5 \mathrm{~mL}$ ) were extracted by liquid-liquid with $10 \mathrm{~mL}$ of methanol, this procedure was repeated 3 times. Then, the combined extracts were dried over anhydrous sodium sulphate, and after filtration were evaporated under reduced pressure until dryness.

\subsubsection{Cytotoxic Activity}

The cytotoxic capacity of the extracts prepared above was assessed by the sulforhodamine B (Sigma-Aldrich, St. Louis, MO, USA) assay against a non-tumor cell line (PLP2, porcine liver primary cells) (acquired from Leibniz-Institut DSMZ). The same assay was also used to evaluate the extracts cytotoxicity against four human tumor cell lines, namely HeLa (cervical carcinoma), HepG2 (hepatocellular carcinoma), MCF-7 (breast adenocarcinoma), and NCI-H460 (non-small cell lung cancer), accordingly a procedure described by the authors $[43,44]$. Ellipticine (Sigma- Aldrich, St. Louis, MO, USA) was used as a positive control. The results were expressed in GI50 values $(\mu \mathrm{g} / \mathrm{mL})$, corresponding to the 
extract concentration responsible for $50 \%$ inhibition of growth in a primary culture of liver cells-PLP2 or in human tumor cell lines.

\subsubsection{Antimicrobial Activity Evaluation}

The following Gram (+) bacteria: Staphylococcus aureus (ATCC 11632), Bacillus cereus (food isolate), and Micrococcus flavus (ATCC 10240), as well as Gram (-) bacteria Enterobacter cloacae (ATCC 35030), Salmonella typhimurium (ATCC 13311), and Escherichia coli (ATCC 25922) were selected to test the antibacterial activity of the extracts. Fungi Aspergillus fumigatus (ATCC 9197), Aspergillus versicolor (ATCC 11730), Aspergillus niger (ATCC 6275), Penicillium funiculosum (ATCC 36839), Penicillium verrucosum var. cyclopium (food isolate), and Trichoderma viride (IAM 5061) were selected to test the antifungal activity of the extracts. The microorganisms were obtained from the Mycological Laboratory, Department of Plant Physiology, Institute for Biological Research "Siniša Stanković", University of Belgrade, National Institute of Republic of Serbia.

The extracts were redissolved in 5\% dimethyl sulfoxide (DMSO) and the microdilution method was used as previously mentioned by the authors [45]. The results were presented as minimum inhibitory/bactericidal concentrations (MICs/MBCs) in case of bacteria and minimum inhibitory/fungicidal concentrations (MICs/MFCs) for fungi; E211 (sodium benzoate) and E224 (potassium metabisulphite) were used as positive controls and 5\% DMSO was used as a negative control.

\subsection{Statistical Analysis}

Throughout this work, results are expressed as mean \pm standard deviation. An analysis of variance (ANOVA) was used to determine the statistical difference among the samples. Mean and standard deviations were determined from the obtained data using Microsoft Excel (Microsoft Corp., Redmond, WA, USA). ANOVA was performed with the use of Statgraphics 5.1.plus (Statpoint Technologies, Inc., Warrenton, VA, USA).

\section{Results and Discussion}

The fatty acids composition of the studied seed oils is presented in Table 1, where fifteen individual fatty acids were detected. All the oils contained almost the same fatty acids, except for the case of pentadecanoic acid (C15:0) which was detected only in purslane seed oils, docosadienoic acid (C22:2) which was identified in linseed and luffa oils, and lignoceric acid (C24:0) which was found only in pumpkin oil. Polyunsaturated fatty acids were the most abundant class in all the studied oils (55.92-85.51\%), followed by monounsaturated and saturated fatty acids (MUFA and SFA, respectively) in amounts that differed depending on the studied oil. This result is within the same range with previous reports regarding linseed [17], luffa [26], purslane [11], and pumpkin [17] seed oils where unsaturated fatty acids were the predominant class, although at slightly different amounts. These differences could be attributed to different extraction methods between the studies or the different genotypes tested, as already pointed out Petropoulos et al. [10,11].

Moreover, fatty acids profile varied among the studied oils. In particular, $\alpha$-linolenic acid (C18:3n3) was the most abundant fatty acid in the case of linseed oils $(71.90 \%, 70.93 \%$, and $65.62 \%$ for linseed oil 1,2, and 3, respectively), while the second most abundant compound was linoleic acid (C18:2n6c) followed by oleic $(\mathrm{C} 18: 1 \mathrm{n} 9 \mathrm{c})$, palmitic (C16:0), and stearic (C18:0) acids. Similarly, to our study, Zamani Ghaleshahi et al. [46] suggested $\alpha$-linolenic as the most abundant fatty acid, while the next most important fatty acids were oleic, palmitic, and stearic acids. However, despite the similarities, the detected amounts in the tested samples of our study were higher than these reports, especially in the case of $\alpha$-linolenic acid, indicating differences in the extraction method and probably the genotypes tested. Moreover, Tavarini et al. [20], who tested two linseed varieties (Bethune and Solal), also observed significant differences in fatty acids profile, especially in the case of $\alpha$-linolenic acid which was considerably higher in Bethune compared to Solal genotype which was a low linolenic mutant $(64.02 \mathrm{~g} / 100 \mathrm{~g}$ fatty acids and $3.96 \mathrm{~g} / 100 \mathrm{~g}$ fatty acids, 
respectively). These effects could be also observed in our study, where the fatty acids profile differed among the three linseed tested oils. However, according to Ren et al. [47], seed pretreatment may significantly increase extraction yield without affecting the fatty acids profile, while Gutte et al. [48] did not detect differences in fatty acids profile of oils extracted with solvent or ultrasonic assisted.

Table 1. Fatty acids composition (\%) of the studied vegetable oils (mean \pm SD).

\begin{tabular}{lcccccc}
\hline Fatty Acids & Linseed Oil 1 & Linseed Oil 2 & Linseed Oil 3 & Luffa Oil & Purslane Oil & Pumpkin Oil \\
\hline C14:0 & $0.042 \pm 0.001 \mathrm{e}$ & $0.043 \pm 0.001 \mathrm{e}$ & $0.054 \pm 0.001 \mathrm{c}$ & $0.095 \pm 0.002 \mathrm{~b}$ & $0.049 \pm 0.001 \mathrm{c}$ & $0.155 \pm 0.003 \mathrm{a}$ \\
C15:0 & - & - & - & - & $0.028 \pm 0.001$ & - \\
C16:0 & $4.61 \pm 0.04 \mathrm{e}$ & $4.32 \pm 0.04 \mathrm{f}$ & $5.36 \pm 0.01 \mathrm{~d}$ & $13.77 \pm 0.07 \mathrm{c}$ & $14.1 \pm 0.1 \mathrm{~b}$ & $14.72 \pm 0.05 \mathrm{a}$ \\
C16:1 & $0.068 \pm 0.004 \mathrm{c}$ & $0.044 \pm 0.001 \mathrm{~d}$ & $0.086 \pm 0.004 \mathrm{~b}$ & $0.153 \pm 0.005 \mathrm{a}$ & $0.086 \pm 0.001 \mathrm{~b}$ & $0.15 \pm 0.01 \mathrm{a}$ \\
C17:0 & $0.057 \pm 0.004 \mathrm{e}$ & $0.055 \pm 0.004 \mathrm{e}$ & $0.072 \pm 0.002 \mathrm{c}$ & $0.166 \pm 0.004 \mathrm{a}$ & $0.105 \pm 0.003 \mathrm{c}$ & $0.113 \pm 0.002 \mathrm{~b}$ \\
C18:0 & $2.85 \pm 0.01 \mathrm{~d}$ & $3.10 \pm 0.01 \mathrm{c}$ & $3.06 \pm 0.01 \mathrm{c}$ & $6.99 \pm 0.02 \mathrm{a}$ & $3.046 \pm 0.006 \mathrm{c}$ & $6.24 \pm 0.01 \mathrm{~b}$ \\
C18:1n9c & $7.09 \pm 0.01 \mathrm{c}$ & $6.43 \pm 0.01 \mathrm{e}$ & $6.95 \pm 0.01 \mathrm{~d}$ & $15.14 \pm 0.03 \mathrm{~b}$ & $5.24 \pm 0.02 \mathrm{f}$ & $21.76 \pm 0.01 \mathrm{a}$ \\
C18:2n6c & $12.87 \pm 0.01 \mathrm{f}$ & $14.58 \pm 0.01 \mathrm{e}$ & $17.98 \pm 0.02 \mathrm{~d}$ & $61.86 \pm 0.01 \mathrm{a}$ & $34.10 \pm 0.05 \mathrm{c}$ & $55.25 \pm 0.05 \mathrm{~b}$ \\
C18:3n3 & $71.90 \pm 0.05 \mathrm{a}$ & $70.93 \pm 0.01 \mathrm{~b}$ & $65.62 \pm 0.04 \mathrm{c}$ & $0.94 \pm 0.02 \mathrm{f}$ & $41.25 \pm 0.08 \mathrm{e}$ & $0.323 \pm 0.006 \mathrm{~g}$ \\
C20:0 & $0.095 \pm 0.002 \mathrm{e}$ & $0.102 \pm 0.001 \mathrm{e}$ & $0.153 \pm 0.001 \mathrm{~d}$ & $0.312 \pm 0.003 \mathrm{c}$ & $0.60 \pm 0.01 \mathrm{a}$ & $0.401 \pm 0.005 \mathrm{~b}$ \\
C20:1 & $0.080 \pm 0.002 \mathrm{c}$ & $0.081 \pm 0.001 \mathrm{c}$ & $0.124 \pm 0.002 \mathrm{a}$ & $0.057 \pm 0.001 \mathrm{~d}$ & $0.102 \pm 0.001 \mathrm{~b}$ & $0.119 \pm 0.008 \mathrm{a}$ \\
C22:0 & $0.081 \pm 0.001 \mathrm{e}$ & $0.088 \pm 0.005 \mathrm{~d}$ & $0.133 \pm 0.004 \mathrm{c}$ & $0.092 \pm 0.006 \mathrm{~d}$ & $0.25 \pm 0.01 \mathrm{a}$ & $0.144 \pm 0.002 \mathrm{~b}$ \\
C22:2 & - & - & - & - & $0.49 \pm 0.05 \mathrm{a}$ & $0.35 \pm 0.03 \mathrm{~b}$ \\
C23:0 & $0.186 \pm 0.004 \mathrm{e}$ & $0.164 \pm 0.002 \mathrm{f}$ & $0.222 \pm 0.005 \mathrm{~d}$ & $0.251 \pm 0.001 \mathrm{c}$ & $0.51 \pm 0.01 \mathrm{a}$ & $0.292 \pm 0.003 \mathrm{~b}$ \\
C24:0 & $0.085 \pm 0.005 \mathrm{~b}$ & $0.061 \pm 0.001 \mathrm{c}$ & $0.183 \pm 0.002 \mathrm{a}$ & $0.180 \pm 0.001 \mathrm{a}$ & - & - \\
\hline SFA & $8.01 \pm 0.04 \mathrm{e}$ & $7.94 \pm 0.02 \mathrm{f}$ & $9.24 \pm 0.01 \mathrm{~d}$ & $21.86 \pm 0.06 \mathrm{~b}$ & $18.7 \pm 0.1 \mathrm{c}$ & $22.06 \pm 0.06 \mathrm{a}$ \\
MUFA & $7.24 \pm 0.01 \mathrm{c}$ & $6.56 \pm 0.01 \mathrm{~d}$ & $7.16 \pm 0.01 \mathrm{~d}$ & $15.35 \pm 0.03 \mathrm{~b}$ & $5.43 \pm 0.02 \mathrm{e}$ & $22.03 \pm 0.02 \mathrm{a}$ \\
PUFA & $84.76 \pm 0.04 \mathrm{~b}$ & $85.51 \pm 0.01 \mathrm{a}$ & $83.60 \pm 0.02 \mathrm{c}$ & $62.79 \pm 0.04 \mathrm{e}$ & $75.83 \pm 0.08 \mathrm{~d}$ & $55.92 \pm 0.08 \mathrm{f}$ \\
PUFA/SFA & $10.58 \pm 0.02 \mathrm{~b}$ & $10.77 \pm 0.01 \mathrm{a}$ & $9.05 \pm 0.01 \mathrm{c}$ & $2.87 \pm 0.05 \mathrm{e}$ & $4.06 \pm 0.04 \mathrm{~d}$ & $2.55 \pm 0.07 \mathrm{f}$ \\
n6/n3 & $0.18 \pm 0.03 \mathrm{e}$ & $0.21 \pm 0.01 \mathrm{e}$ & $0.27 \pm 0.03 \mathrm{~d}$ & $65.81 \pm 0.02 \mathrm{~b}$ & $0.83 \pm 0.06 \mathrm{c}$ & $166.57 \pm 0.03 \mathrm{a}$ \\
\hline
\end{tabular}

C14:0 myristic acid; C15:0 pentadecanoic acid; C16:0 palmitic acid; C16:1 palmitoleic acid; C17:0 heptadecanoic acid; C18:0 stearic acid; C18:1n9c oleic acid; C18:2n6c linoleic acid; C18:3n 3 -linolenic acid; C20:0 arachidic acid; C20:1 eicosenoic acid; C22:0 behenic acid; C22:2 docosadienoic acid; C23:0 tricosylic acid; C24:0 lignoceric acid; SFA: saturated fatty acids; MUFA: monounsaturated fatty acids; PUFA: polyunsaturated fatty acids; n6/n3: ratio of omega-6/omega-3 fatty acids; -: not detected. In each row, different letters mean statistical differences among samples.

In the case of luffa seed oil, it included mostly linoleic acid (61.86\%) followed by oleic acid and palmitic detected in similar amounts (15.14\% and $13.77 \%$, respectively), and stearic acid which was found in lesser amounts (6.99\%). A similar profile was reported by Stevenson et al. [26] and Adewuyi et al. [39], although they reported a lower content of linoleic acid compared to our study $(43.7 \%, 46.8 \%$, and $46.1 \%$, respectively). It seems that as in the case of linseed oil the detected differences could be attributed to the extraction methods since Stevenson et al. [26] extracted oil via supercritical and solvent extraction, while Adewuyi et al. [39] implemented the Soxhlet extraction method.

Purslane seed oil was also a rich source of $\alpha$-linolenic acid $(41.25 \%)$ and linoleic acid $(34.10 \%)$, followed by palmitic, oleic, and stearic acids (14.1\%, $5.2 \%$, and $3.0 \%$, respectively). In contrast, Dubois et al. [17] reported a slightly higher content of linoleic than $\alpha$-linolenic acid (34.1\% and 32.4\%, respectively), while Liu et al. [49] suggested significant differences between wild and cultivated genotypes of purslane, with wild ones containing significantly higher amounts of $\alpha$-linolenic than linoleic acid. Regarding the extracting method, Sodeifian et al. [8] did not observe any differences in fatty acids profile between the Soxhlet and solvent extraction methods, whereas Petropoulos et al. [11] suggested the extraction conditions (e.g., cold extraction vs heat extraction) may affect the content of $\alpha$-linolenic acid and consequently improve the nutritional value and bioactive properties of oil. However, this was not the case in the study of Delfan-Hosseini et al. [50] who compared solvent extraction with cold-pressing and the combination of seed pretreatment with microwaves prior to cold-pressing, and did not observe any differences. This contradiction could be attributed to the fact that cold-pressing in the later report refers to room conditions where 
extraction took place, since no cooling module was described as in the case of Petropoulos et al. [11]. According to Ionescu et al. [51], several operational parameters (e.g., screw speed, press nozzle size, and pressure), may affect not only extraction yield but also oil composition, since they affect temperature conditions during extraction.

Finally, pumpkin oil showed similarities with luffa oil and contained slightly less linoleic and more oleic acid (55.25\% and $21.76 \%$, respectively), while palmitic and oleic acids were found in amounts similar to luffa oil. The detected fatty acid profile in pumpkin seed oil of our study was similar to the one suggested by Nederal et al. [29], whereas Nyam et al. [52] reported higher amounts of oleic than linoleic acid in Cucurbita pepo seeds ( $42.8 \%$ and $30.4 \%$, respectively). Considering the numerous genotypes and the differences in fatty acid profiles among the seed oils of various cultivars, it is difficult to suggest a specific composition for pumpkin oil, since there are genotypes with similar amounts of linoleic and oleic acid, while others contain more linoleic than oleic acid, as in the case of our study [26]. Moreover, according to Murkovic et al. [53], linoleic acid content are highly correlated to each other and linoleic acid is formed after the dehydrogenation of oleic acid. In the same study, it was also suggested that earliness in maturity of pumpkin fruit and environmental conditions may also affect fatty acid composition in seeds and consequently in seed oils [53]. Therefore, late harvesting under low temperatures may result in higher linoleic acid and polyunsaturated fatty acids content due to higher activity of oleoyl phosphatidylcholine desaturase [54].

The values of PUFA/SFA ratio were higher than 0.45 for all the studied oils, indicating a high nutritional value, especially in the case of linseed oils where the highest values were recorded (9.05-10.77), whereas pumpkin oil values were marginally higher than this threshold [55-57]. Similarly, n6/n3 ratio was lower than 4.0 in linseed and purslane seed oils due to their high content in omega- 3 fatty acids and $\alpha$-linolenic acid in particular. On the other hand, the values of $n 6 / \mathrm{n} 3$ recorded for luffa and pumpkin seed oils were considerably higher than 4.0 due to their high content of omega- 6 fatty acids (linoleic acid) and the very low amounts of $\alpha$-linolenic acid. The recorded values for both ratios are in agreement with the literature reports as already described [17,26,29,46,53], except for the cases where genotypic differences or differences in the extraction protocols were identified [20,49,52]. According to Guil et al. [55], both these ratios (PUFA/SFA and n6/n3) are good indicators for the nutritional quality of a food product, however even in the case of pumpkin and luffa oils which did not met this specific criterion, there are several beneficial health effects evidenced that allow us to suggest their incorporation in the human diet. Moreover, it seems that the extraction with cold pressing may improve the nutritional value of seed oils by increasing the beneficial fatty acids content, such as $\alpha$-linolenic acid in the case of linseed and purslane seed oil, thus improving the nutritional value and the bioactive properties of the obtained oils [58].

The cytotoxic effects of the studied oils are described in Table 2. None of the tested oils were effective against all the tested tumor cell lines, while linseed oil 1, luffa oil, and cucurbit showed a slight toxicity against the non-tumor porcine liver primary culture (PLP2) cell line. Moreover, all the tested oils (except for linseed oil 1 and 2) showed efficacy against cervical carcinoma (HeLa) cell lines, especially luffa oil which recorded the lowest $\mathrm{GI}_{50}$ values $(215 \mu \mathrm{g} / \mathrm{mL})$, followed by pumpkin oil, linseed oil 1, and purslane oil in decreasing order of effectiveness. Similarly, luffa oil was the most efficient against non-small cell lung cancer (NCI-H460) cell line, followed by linseed oil 1, whereas none of the tested oils were effective against hepatocellular carcinoma (HepG2) and breast carcinoma (MCF-7) cell lines. The anticancer activities of Luffa sp. aerial parts against various types of cancer have been previously reported (e.g., human neuronal glioblastoma cells (U343) and human lung cancer cells (A549) [59], human lung cancer cell line (NCI-H460) [60], Ehrlich ascites carcinoma (EAC) [61], Dalton's lymphoma ascites (DLA) [62]); however, to the best of our knowledge there are no reports regarding the cytotoxic effects of luffa seed oil against cancer cell lines and the results of our study could be useful for the exploitation of this underutilized species. Linseed is also well known for its anticancer activities, especially 
against hormone related cancers such as breast, prostate, and colon cancer, due to its high content in $\alpha$-linolenic acid and polyphenols which reduce human estrogen receptorpositive tumors and inhibit cancer cells proliferation [63-65]. Therefore, our results are in agreement with those of literature reports, although it seems that bioactive properties of oils are related to the extraction protocol since not all the tested oils of this study presented similar cytotoxic effects.

Table 2. Cytotoxicity and antitumor activity of the studied vegetable oils ( $\mathrm{GI}_{50}$ values $\left.\mu \mathrm{g} / \mathrm{mL}\right)$.

\begin{tabular}{|c|c|c|c|c|c|}
\hline \multirow[b]{2}{*}{ Seed Oil } & \multirow{2}{*}{$\begin{array}{c}\text { Cytotoxicity to Non-Tumor Cell Lines } \\
\text { PLP2 } \\
\text { (Porcine Liver Primary Culture) }\end{array}$} & \multicolumn{4}{|c|}{ Cytotoxicity to Tumor Cell Lines } \\
\hline & & $\begin{array}{c}\text { HeLa } \\
\text { (Cervical } \\
\text { Carcinoma) }\end{array}$ & $\begin{array}{c}\text { HepG2 } \\
\text { (Hepatocellular } \\
\text { Carcinoma) }\end{array}$ & $\begin{array}{c}\text { MCF-7 } \\
\text { (Breast } \\
\text { Carcinoma) }\end{array}$ & $\begin{array}{c}\text { NCI-H460 } \\
\text { (Non-Small Cell } \\
\text { Lung Cancer) }\end{array}$ \\
\hline Linseed oil 1 & $301 \pm 23 a$ & $291 \pm 27 b$ & $>400$ & $>400$ & $369 \pm 33 a$ \\
\hline Linseed oil 2 & $>400$ & $>400$ & $>400$ & $>400$ & $>400$ \\
\hline Linseed oil 3 & $>400$ & $>400$ & $>400$ & $>400$ & $>400$ \\
\hline Luffa oil & $215 \pm 17 c$ & $189 \pm 17 \mathrm{C}$ & $>400$ & $>400$ & $136 \pm 12 b$ \\
\hline Purslane oil & $>400$ & $307 \pm 12 a$ & $>400$ & $>400$ & $>400$ \\
\hline Pumpkin oil & $259 \pm 21 b$ & $270 \pm 25 b$ & $>400$ & $>400$ & $>400$ \\
\hline
\end{tabular}

$\mathrm{GI}_{50}$ values correspond to the sample concentration responsible for $50 \%$ inhibition of growth in a primary culture of liver cells-PLP2 or in human tumor cell lines or. GI 50 values for Ellipticine (positive control): $3 \mu \mathrm{g} / \mathrm{mL}$ (PLP2), $1.0 \mu \mathrm{g} / \mathrm{mL}$ (MCF-7), 1.0 $\mu \mathrm{g} / \mathrm{mL}$ (NCI-H460), $2.0 \mu \mathrm{g} / \mathrm{mL}$ (HeLa) and $1.0 \mu \mathrm{g} / \mathrm{mL}$ (HepG2). In each row, different letters mean statistical differences among samples.

Regarding pumpkin seeds and seed oil, both in vitro and in vivo studies have reported the beneficial effects against hyperplastic and cancer cells, as in the case of prostate hyperplasia [66], colon cancer [67], or cervical carcinoma [68]. According to Colagar and Souraki [69] the anticancer effects of pumpkin seed oil could be attributed to antioxidant vitamins which inhibit free radicals production, while Heng et al. [70] associated toxic effects against melanoma cells to moschatin, a ribosome inactivating protein. In a recent study conducted by Khan et al. [71], cucurbitacin obtained from seeds exhibited antiproliferative effects against non-small cell lung cancer cells, while Bardaa et al. [72] reported that bioactive properties of seed oil could be due to high content not only of polyunsaturated fatty acids, but also to tocopherols and phytosterols. Moreover, Al-Okbi et al. [73] reported significant inhibitory effects of Cucurbita moschata and C. pepo seed oils against liver, colon, and breast cancer, and suggested potential uses in controlling tumor proliferation.

The lack of toxic effects or genotoxicity of purslane has been previously reported for aqueous extracts of aerial plant parts, indicating they are safe for edible purposes [74], while moderate toxic effects were suggested for solvent extracts against human lung (K562 and A549) and breast (MCF-7 and MDA-MB-435) cancer cell lines [75], nasopharyngeal cancer (CNE-1), colon cancer (HT-29), and cervical cancer (HeLa). The abovementioned reports refer to aerial plant parts (stems and leaves), while the work of Al-Sheddi et al. [76] suggested significant cytotoxic and anti-proliferative effects of purslane seed extracts or seed oil against HeLa and A549 cell lines. According to Al-Sheddi et al. [76] purslane seed oil may exert significant in vitro cytotoxic effects against cell lines of human liver (HepG2) and human lung cancer (A-549). Moreover, Asif suggested that the anticancer activities of seed oils could be attributed to polyunsaturated fatty acids, especially a group of conjugated isomers of linoleic acid [5].

The antibacterial properties of the tested oils are presented in Table 3. A varied effectiveness was recorded against the tested bacteria depending on the oil source. In particular, all the oils exhibited high bactericidal and growth inhibitory effects against S. aureus and M. flavus with MIC and MBC similar to E211 and E224 (positive controls), respectively (except for linseed oil 2 and purslane oil, which showed the lowest activity in the case of $S$. aureus and $M$. flavus, respectively). Moreover, all the tested oils were similarly or more effective than E224 against B. cereus, while E211 was the most effective. Linseed oil 2 and luffa oil recorded MIC values similar to E224 against E. cloacae, while (with the 
exception of purslane oil) the rest of the tested oils were more effective than the other positive control (E211). Regarding S. typhimurium, the tested oils (except for linseed oil 2 and purslane oil) were similarly effective to positive controls, apart from E224 which recorded the lowest MBC values. Finally, linseed oil 3 and pumpkin oil showed higher effectiveness against $E$. coli than the rest of the oils and similar to E224.

The antibacterial activities of flaxseed oil are well documented and variable effects have been suggested against bacteria, such as methicillin resistant $S$. aureus (MRSA), methicillin sensitive S. aureus (MSSA), K. pneumoniae and S. epidermidis, whereas no effectiveness against E. coli and E. faecalis was observed [77]. Similarly, Kaithwas et al. [78] suggested effectiveness of flaxseed oil against a broad spectrum of bacteria (e.g., S. aureus, Streptococcus agalactiae, E. coli, E. faecalis, and M. luteus) was with antimicrobial activity comparable to or better than the positive control (cefoperazone). According to Santos et al. [79], flaxseed oil exhibited significant antibacterial activity against Salmonella enteritidis and S. typhimurium and no inhibitory effects against $S$. aureus, L. monocytogenes, and B. cereus. The same authors also suggested that cultivation practices may affect the bioactive properties of the obtained oils, with oils extracted from seeds of organically grown plants being more potent than those of conventionally grown ones [79]. This seems to be the case in our study, since linseed oil 3 (organic oil) was more effective against $E$. coli than the other two linseed oils, while for the rest of the tested bacteria no differences were observed in MIC and MBC from linseed oil 2. Moreover, Joshi et al. [80] suggested the complementary use of flaxseed oil along with gemifloxacin to increase its effectiveness and reduce the development of resistance.

Table 3. Antibacterial activity of the studied seed oils (MIC and MBC mg/mL).

\begin{tabular}{|c|c|c|c|c|c|c|c|c|c|c|c|c|}
\hline \multirow[t]{2}{*}{ Seed Oil } & \multicolumn{2}{|c|}{$\begin{array}{c}\text { Staphylococcus } \\
\text { aureus } \\
\text { (ATCC 11632) }\end{array}$} & \multicolumn{2}{|c|}{$\begin{array}{l}\text { Bacillus cereus } \\
\text { (Food Isolate) }\end{array}$} & \multicolumn{2}{|c|}{$\begin{array}{c}\text { Micrococcus } \\
\text { flavus (ATCC } \\
10240)\end{array}$} & \multicolumn{2}{|c|}{$\begin{array}{c}\text { Enterobacter } \\
\text { cloacae } \\
\text { (ATCC 35030) }\end{array}$} & \multicolumn{2}{|c|}{$\begin{array}{c}\text { Salmonella } \\
\text { Typhimurium } \\
\text { (ATCC 13311) }\end{array}$} & \multicolumn{2}{|c|}{$\begin{array}{l}\text { Escherichia coli } \\
\text { (ATCC 25922) }\end{array}$} \\
\hline & MIC & MBC & MIC & MBC & MIC & MBC & MIC & MBC & MIC & MBC & MIC & MBC \\
\hline Linseed oil 1 & 2.00 & 4.00 & 1.00 & 2.00 & 1.00 & 2.00 & 1.00 & 2.00 & 1.00 & 2.00 & 1.00 & 2.00 \\
\hline Linseed oil 2 & 4.00 & 8.00 & 1.00 & 2.00 & 1.00 & 2.00 & 0.50 & 1.00 & 2.00 & 4.00 & 2.00 & 4.00 \\
\hline Linseed oil 3 & 2.00 & 4.00 & 1.00 & 2.00 & 1.00 & 2.00 & 1.00 & 2.00 & 1.00 & 2.00 & 0.50 & 1.00 \\
\hline Luffa oil & 2.00 & 4.00 & 1.00 & 2.00 & 1.00 & 2.00 & 0.50 & 1.00 & 1.00 & 2.00 & 2.00 & 4.00 \\
\hline Purslane oil & 2.00 & 4.00 & 2.00 & 4.00 & 2.00 & 4.00 & 2.00 & 4.00 & 2.00 & 4.00 & 1.00 & 2.00 \\
\hline Cucurbit oil & 2.00 & 4.00 & 1.00 & 2.00 & 1.00 & 2.00 & 1.00 & 2.00 & 1.00 & 2.00 & 0.50 & 1.00 \\
\hline E211 & 4.00 & 4.00 & 0.50 & 0.50 & 1.00 & 2.00 & 2.00 & 4.00 & 1.00 & 2.00 & 1.00 & 2.00 \\
\hline E224 & 1.00 & 1.00 & 2.00 & 4.00 & 1.00 & 2.00 & 0.50 & 0.50 & 1.00 & 1.00 & 0.50 & 1.00 \\
\hline
\end{tabular}

MIC: minimum inhibition concentration; MBC: minimum bactericidal concentration; E211: sodium benzoate; E224: potassium metabisulphite.

The studies of antibacterial effects of luffa refer to aerial plant parts and seeds with limited research available on seed oil effects [42,62]. According to Swain et al. [81], luffa seed oils showed effectiveness against a wide range of bacteria (e.g., S. aureus, S. epidermidis, Micrococcus leutius, Pseudomonas aeruginosa, and E. coli), while in all the cases the obtained MIC values were lower than the positive control used. Similarly, the reports for the antibacterial effects of purslane are limited, especially for seed oils [82-85]. According to Tayel et al. [86], purslane seed extracts were only effective against normal S. aureus strains, while Bakkiyaraj and Pandiyaraj [87] also recorded effectiveness of leaf extracts against $S$. aureus, B. aureus, and P. aeruginosa. Recently, Petropoulos et al. [11] reported low effectiveness of purslane seed oil against different Gram+ and Gram- bacteria, although they suggested that raw seeds were more effective than seedcakes and seed oils, probably due to loss of bioactive compounds during the extraction procedure. In contrast, Othman [88] found significant effectiveness of purslane fixed oil against S. epidermidis and E. coli and attributed this activity to the high content of omega- 3 fatty acids. 
Regarding pumpkin oil, Obi et al. [32] reported significant inhibitory effects of Cucurbita pepo seed oils against $S$. aureus and E. coli and attributed these effects to the presence of bioactive compounds such as tannins, flavonoids, cyanogenic glycosides, cardiac glycosides, and saponins. Moreover, Bardaa et al. [72] reported significant inhibitory effects of pumpkin seed oil against Bacillus subtilis, while Amin et al. [31] suggested high effectiveness against various E. coli strains and Shigella sonnei and further reported significantly higher antibacterial activity in oils obtained from an indigenous genotype compared to a hybrid. Moreover, in an earlier study of the same authors, the oil of indigenous pumpkin seeds contained higher amounts (2.5 times higher) of tocopherols than a hybrid pumpkin, a finding that could justify the better antibacterial efficacy of this particular oil [31]. In contrast, Hammer et al. [89] classified pumpkin oil among the plant extracts that did not show any inhibitory effects against several bacteria when applied at the highest tested concentration $(2.0 \% ; v / v)$.

From the results of this study it could be concluded that fatty acids composition is essential for the antibacterial properties of the tested oils. In their review report, Yoo et al. [58] highlighted the broad spectrum of antibacterial activity of lipids with emphasis on fatty acids with 18 carbons such as $\alpha$-linolenic, linoleic, and oleic acid, which were the most prevalent fatty acids in the oils of our study as well. Moreover, Xuan et al. [90], who studied antibacterial effects of various edible oils, highlighted the differences in total phenolic and total flavonoids content as well as to individual compounds of the tested oils as responsible for the varied antibacterial efficacy. However, despite the differences in chemical composition, there was no positive correlation of phenolics and flavonoids with antibacterial effects against $S$. aureus and E. coli. Moreover, the processing grade may also affect antibacterial effects with crude oils being more effective than the refined ones, indicating the loss of valuable compounds during the refining process [91]. These findings suggest that other antioxidant compounds apart from lipids are responsible for the antibacterial effects of vegetable oils (e.g., tocopherols or species specific compounds) which could justify the observed differences among the studied oils of our study. Moreover, agronomic practices and the extraction method may also have an effect on bioactive properties of seed oils, as evidenced in the case of our study with different linseed oils.

The antifungal properties of the seed oils of our study are shown in Table 4 with the tested oils being more effective than the positive controls in several occasions. In particular, linseed oil 1 and 3 were more effective against $A$. fumigatus compared not only to the rest of the tested oils, but also to the used controls. Similarly, luffa and cucurbit oils were the most effective against $A$. versicolor, A. niger, P. funiculosum, and P. verrucosum var. cyclopium, without differences from linseed oil 3 in the case of $A$. niger, and linseed oil 2 in the case of P. funiculosum and P. verrucosum var. cyclopium. Finally, linseed oil 2 and luffa oil were the most effective against $T$. viride with MIC values equal to E224. Purslane seed oil and linseed oil 3 (except for the case of $A$. niger) had the least overall effectiveness against the tested fungi, since in most cases they recorded the highest MIC and MFC values.

Table 4. Antifungal activity of the studied seed oils (MIC and MFC mg/mL).

\begin{tabular}{|c|c|c|c|c|c|c|c|c|c|c|c|c|}
\hline \multirow[t]{2}{*}{ Seed Oil } & \multicolumn{2}{|c|}{$\begin{array}{c}\text { Aspergillus } \\
\text { fumigatus } \\
\text { (ATCC 9197) }\end{array}$} & \multicolumn{2}{|c|}{$\begin{array}{c}\text { Aspergillus } \\
\text { versicolor } \\
\text { (ATCC 11730) }\end{array}$} & \multicolumn{2}{|c|}{$\begin{array}{c}\text { Aspergillus niger } \\
\text { (ATCC 6275) }\end{array}$} & \multicolumn{2}{|c|}{$\begin{array}{l}\text { Penicillium } \\
\text { funiculosum } \\
\text { (ATCC 36839) }\end{array}$} & \multicolumn{2}{|c|}{$\begin{array}{c}\text { Penicillium } \\
\text { verrucosum var. } \\
\text { cyclopium } \\
\text { (Food Isolate) }\end{array}$} & \multicolumn{2}{|c|}{$\begin{array}{c}\text { Trichoderma } \\
\text { viride (IAM 5061) }\end{array}$} \\
\hline & MIC & MFC & MIC & MFC & MIC & MFC & MIC & MFC & MIC & MFC & MIC & MFC \\
\hline Linseed oil 1 & 0.50 & 1.00 & 1.00 & 2.00 & 2.00 & 4.00 & 2.00 & 4.00 & 1.00 & 2.00 & 1.00 & 2.00 \\
\hline Linseed oil 2 & 2.00 & 4.00 & 1.00 & 2.00 & 1.00 & 2.00 & 0.5 & 1.00 & 0.5 & 1.00 & 0.5 & 1.00 \\
\hline Linseed oil 3 & 1.00 & 2.00 & 2.00 & 4.00 & 0.50 & 1.00 & 2.00 & 4.00 & 2.00 & 4.00 & 2.00 & 4.00 \\
\hline Luffa oil & 0.50 & 1.00 & 0.50 & 1.00 & 0.50 & 1.00 & 0.50 & 1.00 & 0.50 & 1.00 & 0.50 & 1.00 \\
\hline Purslane oil & 4.00 & 8.00 & 2.00 & 4.00 & 2.00 & 4.00 & 2.00 & 4.00 & 2.00 & 4.00 & 2.00 & 4.00 \\
\hline Cucurbit oil & 1.00 & 2.00 & 0.50 & 1.00 & 0.50 & 1.00 & 0.50 & 1.00 & 0.50 & 1.00 & 1.00 & 2.00 \\
\hline
\end{tabular}


Table 4. Cont.

\begin{tabular}{|c|c|c|c|c|c|c|c|c|c|c|c|c|}
\hline \multirow[t]{2}{*}{ Seed Oil } & \multicolumn{2}{|c|}{$\begin{array}{c}\text { Aspergillus } \\
\text { fumigatus } \\
\text { (ATCC 9197) }\end{array}$} & \multicolumn{2}{|c|}{$\begin{array}{c}\text { Aspergillus } \\
\text { versicolor } \\
\text { (ATCC 11730) }\end{array}$} & \multicolumn{2}{|c|}{$\begin{array}{l}\text { Aspergillus niger } \\
\text { (ATCC 6275) }\end{array}$} & \multicolumn{2}{|c|}{$\begin{array}{l}\text { Penicillium } \\
\text { funiculosum } \\
\text { (ATCC 36839) }\end{array}$} & \multicolumn{2}{|c|}{$\begin{array}{c}\text { Penicillium } \\
\text { verrucosum var. } \\
\text { cyclopium } \\
\text { (Food Isolate) }\end{array}$} & \multicolumn{2}{|c|}{$\begin{array}{c}\text { Trichoderma } \\
\text { viride (IAM 5061) }\end{array}$} \\
\hline & MIC & MFC & MIC & MFC & MIC & MFC & MIC & MFC & MIC & MFC & MIC & MFC \\
\hline E211 & 1.00 & 2.00 & 2.00 & 2.00 & 1.00 & 2.00 & 1.00 & 2.00 & 2.00 & 4.00 & 1.00 & 2.00 \\
\hline E224 & 1.00 & 1.00 & 1.00 & 1.00 & 1.00 & 1.00 & 0.50 & 0.50 & 1.00 & 1.00 & 0.50 & 0.50 \\
\hline
\end{tabular}

MIC: minimum inhibition concentration; MFC: minimum fungicidal concentration; E211: sodium benzoate; E224: potassium metabisulphite.

Most of the reports regarding the antimicrobial effects of vegetable seed oils refer to antibacterial activity and limited research is carried out on fungicidal effects. Similarly to our study, Abdelillah et al. [92], who tested the fungicidal activity of linseed oil, reported effectiveness against toxigenic Aspergillus species and further attributed these antifungal effects to the high content of linoleic and $\alpha$-linolenic acids. Swain et al. [81] also recorded higher activity of luffa oil against various fungi strains (e.g., C. albicans, C. tropicalis, Trichophyton rubrum, Epidermophyton flocossum, and Microsporum canis) compared to fluconazole and aqueous or ethanolic extracts of fruit. Recently, Amrithaa and Geetha [93] reported in vitro inhibitory activity of pumpkin oil against Candida albicans when added at $200 \mu \mathrm{L}$, while Abd El-Aziz et al. [94] suggested effectiveness against yeast species such as $C$. albicans and Rhodotorula rubra and lower effectiveness against mold species (e.g., Penicillium chrysogenum, A. parasiticus, and A. niger). Similar results were reported by Sener et al. [95] and Kaithwas et al. [78], who also detected high efficiency of Cucurbita pepo seed oil against $C$. albicans. In contrast, Hammer et al. [89] did not observe any inhibitory effects of pumpkin oil against several bacteria when applied at the highest tested concentration $(2.0 \% ; v / v)$. According to Rabrenović et al. [24], the high content of squalene in pumpkin seed oil could be partly responsible for these antifungal effects, apart from polyunsaturated fatty acids. Similarly to our study, Petropoulos et al. [11] recorded low effectiveness of purslane seed oil against the same bacteria since positive controls exhibited lower MIC and MBC values. It seems that lipids are responsible for the antifungal effects of the studied oils vegetable oils, while other compounds (e.g., squalene in the case of pumpkin oil) may also contribute to the overall antimicrobial activity of seed oils. Moreover, similar to antibacterial, the growing conditions may also affect the antimicrobial properties of the studied oils.

The range of all the tested pathogens used in the study is wide and includes both clinically relevant pathogens and food/crop contaminants, in order not to overlook the extensive potential of natural oils in both food and pharmaceutical industries. Hence, the obtained data, which clearly demonstrates antimicrobial potential towards all the tested pathogens, point to the fact that oils are rich in compounds with this activity. Given that previously published data have shown polyunsaturated acids have significant antibacterial and antifungal potential, it is safe to say that the antimicrobial potential observed for the oils in this study, in part, can be attributed to them.

\section{Conclusions}

Based on the results of our study, the tested less-conventional seed oils showed promising nutritional value regarding their fatty acids profile, with linseed and purslane seed oils having high amounts of health beneficial $\alpha$-linolenic acid. On the other hand, pumpkin and luffa oil were the most abundant in linoleic acid, which is also associated with beneficial health effects. This could be supported by the in vitro cytotoxic activity of luffa oil against cervical carcinoma and non-small cell lung cancer cell lines. The tested oils also showed a varied effectiveness against several Gram+ and Gram- bacteria, especially linseed oil 3 and pumpkin oil, which showed the significant activity against most of the tested bacteria (especially against Enterobacter cloacae and Escherichia coli), although in most of the cases the positive controls exhibited the lowest MIC and MBC values. On the other hand, the antifungal activities were more profound, and the studied oils were more effective than the positive controls for most of the tested fungi, especially luffa and pumpkin oil, 
which showed the best overall performance. Therefore, the studied oils could be used as a source of compounds with antimicrobial potential but have also been exploited for their high nutritional value and cytotoxic effects as a functional ingredient in food products, thus increasing the added value of the corresponding crops. Moreover, further research is needed in order to evaluate the physicochemical properties and bioactive compounds in blends of the studied oils or in blends with other conventional vegetable oils, since synergistic effects may improve the overall bioactive properties of conventional oils.

Author Contributions: Conceptualization, S.A.P., Y.R., I.C.F.R.F., and L.B.; methodology, S.A.P., Â.F., R.C.C., J.P.; software, Â.F., R.C.C., J.P.; validation, Â.F., R.C.C., J.P.; formal analysis, Â.F., R.C.C., J.P.; investigation, Â.F., R.C.C., J.P.; resources, S.A.P., M.S., I.C.F.R.F., and L.B.; data curation, S.A.P., Â.F., R.C.C., J.P.; writing-original draft preparation, S.A.P., Y.R.; writing-review and editing, S.A.P., Y.R., M.S., I.C.F.R.F., and L.B.; visualization, S.A.P.; supervision, S.A.P., M.S. and L.B.; project administration, S.A.P., M.S., L.B.; funding acquisition, S.A.P., Â.F., M.S., L.B. All authors have read and agreed to the published version of the manuscript.

Funding: This work was funded by the General Secretariat for Research and Technology of Greece and PRIMA foundation under the project PULPING (Prima2019-08). The authors are grateful to the Foundation for Science and Technology (FCT, Portugal) for financial support through national funds FCT/MCTES to CIMO (UIDB/00690/2020); for the financial support through national funding from the FCT, within the scope of the Project PRIMA Section 2-Multi-topic 2019: PulpIng (PRIMA/0007/2019); and L. Barros and Â. Fernandes thank the national funding by FCT, P.I., through the institutional scientific employment program-contract for their contracts. The authors are also grateful to the Ministry of Education, Science and Technological Development of the Republic of Serbia, grant number 451-03-9/2021-14/ 200007.

Institutional Review Board Statement: Not applicable.

Informed Consent Statement: Not applicable.

Data Availability Statement: The study did not report any data.

Conflicts of Interest: The authors declare no conflict of interest.

\section{References}

1. Saeed, F.; Afzaal, M.; Tufail, T.; Ahmad, A. Use of Natural Antimicrobial Agents: A Safe Preservation Approach. In Active Antimicrobial Food Packaging; Var, I., Uzunlu, S., Eds.; IntechOpen: London, UK, 2019; Volume 32, pp. 1-18.

2. Quinto, E.J.; Caro, I.; Villalobos-Delgado, L.H.; Mateo, J.; De-Mateo-silleras, B.; Redondo-Del-río, M.P. Food safety through natural antimicrobials. Antibiotics 2019, 8, 208. [CrossRef]

3. Herrero, M.; Cifuentes, A.; Ibañez, E. Sub- and supercritical fluid extraction of functional ingredients from different natural sources: Plants, food-by-products, algae and microalgae-A review. Food Chem. 2006, 98, 136-148. [CrossRef]

4. Isaacs, C.E.; Litov, R.E.; Thormar, H. Antimicrobial activity of lipids added to human milk, infant formula, and bovine milk. J. Nutr. Biochem. 1995, 6, 362-366. [CrossRef]

5. Asif, M. Health effects of omega-3,6,9 fatty acids: Perilla frutescens is a good example of plant oils. Orient. Pharm. Exp. Med. 2011, 11, 51-59. [CrossRef]

6. Arshad, M.S.; Batool, S.A. Natural Antimicrobials, their Sources and Food Safety. In Food Additives; Karunaratne, D.N., Pamunuwa, G., Eds.; IntechOpen: London, UK, 2017; pp. 87-102, ISBN 9781626239777.

7. Corrêa, R.C.G.; Di Gioia, F.; Ferreira, I.C.F.R.; Petropoulos, S.A. Wild greens used in the Mediterranean diet. In The Mediterranean Diet: An Evidence-based Approach; Preedy, V., Watson, R., Eds.; Academic Press: London, UK, 2020; pp. 209-228, ISBN 9788578110796.

8. Sodeifian, G.; Ardestani, N.S.; Sajadian, S.A.; Moghadamian, K. Properties of Portulaca oleracea seed oil via supercritical fluid extraction: Experimental and optimization. J. Supercrit. Fluids 2018, 135, 34-44. [CrossRef]

9. OECD/FAO. Oilseeds and oilseed products. In OECD-FAO Agricultural Outlook 2016-2025; OECD Publishing: Paris, France, 2016; pp. 127-138.

10. Petropoulos, S.A.; Fernandes, Â.; Calhelha, R.C.; Danalatos, N.; Barros, L.; Ferreira, I.C.F.R. How extraction method affects yield, fatty acids composition and bioactive properties of cardoon seed oil? Ind. Crops Prod. 2018, 124, 459-465. [CrossRef]

11. Petropoulos, S.A.; Fernandes, Â.; Arampatzis, D.A.; Tsiropoulos, N.G.; Petrović, J.; Soković, M.; Barros, L.; Ferreira, I.C.F.R. Seed oil and seed oil byproducts of common purslane (Portulaca oleracea L.): A new insight to plant-based sources rich in omega-3 fatty acids. LWT Food Sci. Technol. 2020, 123, 109099. [CrossRef]

12. Adarme-Vega, T.C.; Thomas-Hall, S.R.; Schenk, P.M. Towards sustainable sources for omega-3 fatty acids production. Curr. Opin. Biotechnol. 2014, 26, 14-18. [CrossRef] 
13. Guil-Guerrero, J.L.; Gómez-Mercado, F.; Ramos-Bueno, R.P.; González-Fernández, M.J.; Urrestarazu, M.; Jiménez-Becker, S.; de Bélair, G. Fatty acid profiles and sn-2 fatty acid distribution of $\gamma$-linolenic acid-rich Borago species. J. Food Compos. Anal. 2018, 66, 74-80. [CrossRef]

14. Meddeb, W.; Rezig, L.; Zarrouk, A.; Nury, T.; Vejux, A.; Prost, M.; Bretillon, L.; Mejri, M.; Lizard, G. Cytoprotective activities of milk thistle seed oil used in traditional tunisian medicine on 7-ketocholesterol and 24S-hydroxycholesterol-induced toxicity on 158N murine oligodendrocytes. Antioxidants 2018, 7, 95. [CrossRef]

15. Siger, A.; Dwiecki, K.; Borzyszkowski, W.; Turski, M.; Rudzińska, M.; Nogala-Kałucka, M. Physicochemical characteristics of the cold-pressed oil obtained from seeds of Fagus sylvatica L. Food Chem. 2017, 225, 239-245. [CrossRef] [PubMed]

16. Kochhar, S.P. Sesame, rice-bran and flaxseed oils. In Vegetable Oils in Food Technology: Composition, Properties and Uses; Gunstone, F.D., Ed.; Blackwell Publishing Inc.: Boca Raton, FL, USA, 2002; pp. 297-326, ISBN 9780123849533.

17. Dubois, V.; Breton, S.; Linder, M.; Fanni, J.; Parmentier, M. Fatty acid profiles of 80 vegetable oils with regard to their nutritional potential. Eur. J. Lipid Sci. Technol. 2007, 109, 710-732. [CrossRef]

18. Wang, S.; Zhu, F.; Kakuda, Y. Sacha inchi (Plukenetia volubilis L.): Nutritional composition, biological activity, and uses. Food Chem. 2018, 265, 316-328. [CrossRef]

19. Hrnčič, M.K.; Ivanovski, M.; Cör, D.; Knez, Ž. Chia Seeds (Salvia hispanica L.): An overview-phytochemical profile, isolation methods, and application. Molecules 2020, 25, 11. [CrossRef]

20. Tavarini, S.; Castagna, A.; Conte, G.; Foschi, L.; Sanmartin, C.; Incrocci, L.; Ranieri, A.; Serra, A.; Angelini, L.G. Evaluation of Chemical Composition of Two Linseed Varieties as Sources of Health-Beneficial Substances. Molecules 2019, 24, 3729. [CrossRef] [PubMed]

21. Dias, M.I.; Ferreira, I.C.F.R.; Barreiro, M.F. Microencapsulation of bioactives for food applications. Food Funct. 2015, 6, 1035-1052. [CrossRef]

22. Le Priol, L.; Gmur, J.; Dagmey, A.; Morandat, S.; El Kirat, K.; Saleh, K.; Nesterenko, A. Co-encapsulation of vegetable oils with phenolic antioxidants and evaluation of their oxidative stability under long-term storage conditions. LWT Food Sci. Technol. 2021, 142, 111033. [CrossRef]

23. Wrona, M.; Silva, F.; Salafranca, J.; Nerín, C.; Alfonso, M.J.; Caballero, M.Á. Design of new natural antioxidant active packaging: Screening flowsheet from pure essential oils and vegetable oils to ex vivo testing in meat samples. Food Control 2021, 120. [CrossRef]

24. Rabrenović, B.B.; Dimić, E.B.; Novaković, M.M.; Tešević, V.V.; Basić, Z.N. The most important bioactive components of cold pressed oil from different pumpkin (Cucurbita pepo L.) seeds. LWT Food Sci. Technol. 2014, 55, 521-527. [CrossRef]

25. Seymen, M.; Uslu, N.; Türkmen, Ö.; Al Juhaimi, F.; Özcan, M.M. Chemical Compositions and Mineral Contents of Some Hull-Less Pumpkin Seed and Oils. JAOCS J. Am. Oil Chem. Soc. 2016, 93, 1095-1099. [CrossRef]

26. Stevenson, D.G.; Eller, F.J.; Wang, L.; Jane, J.L.; Wang, T.; Inglett, G.E. Oil and tocopherol content and composition of pumpkin seed oil in 12 cultivars. J. Agric. Food Chem. 2007, 55, 4005-4013. [CrossRef]

27. Vujasinovic, V.; Djilas, S.; Dimic, E.; Romanic, R.; Takaci, A. Shelf life of cold-pressed pumpkin (Cucurbita pepo L.) seed oil obtained with a screw press. JAOCS J. Am. Oil Chem. Soc. 2010, 87, 1497-1505. [CrossRef]

28. Can-Cauich, C.A.; Sauri-Duch, E.; Moo-Huchin, V.M.; Betancur-Ancona, D.; Cuevas-Glory, L.F. Effect of extraction method and specie on the content of bioactive compounds and antioxidant activity of pumpkin oil from Yucatan, Mexico. Food Chem. 2019, 285, 186-193. [CrossRef]

29. Nederal, S.; Škevin, D.; Kraljić, K.; Obranović, M.; Papeša, S.; Bataljaku, A. Chemical composition and oxidative stability of roasted and cold pressed pumpkin seed oils. JAOCS J. Am. Oil Chem. Soc. 2012, 89, 1763-1770. [CrossRef]

30. Rezig, L.; Chouaibi, M.; Ojeda-Amador, R.M.; Gomez-Alonso, S.; Salvador, M.D.; Fregapane, G.; Hamdi, S. Cucurbita maxima pumpkin seed oil: From the chemical properties to the different extracting techniques. Not. Bot. Horti Agrobot. Cluj-Napoca 2018, 46, 663-669. [CrossRef]

31. Amin, M.Z.; Rity, T.I.; Uddin, M.R.; Rahman, M.M.; Uddin, M.J. A comparative assessment of anti-inflammatory, anti-oxidant and anti-bacterial activities of hybrid and indigenous varieties of pumpkin (Cucurbita maxima Linn.) seed oil. Biocatal. Agric. Biotechnol. 2020, 28, 101767. [CrossRef]

32. Obi, R.K.; Nwanebu, F.C.; Ndubuisi, U.U.; Orji, N.M. Antibacterial qualities and phytochemical screening of the oils of Curcubita pepo and Brassica nigra. J. Med. Plants Res. 2009, 3, 429-432.

33. Petropoulos, S.; Karkanis, A.; Fernandes, Â.; Barros, L.; Ferreira, I.C.F.R.; Ntatsi, G.; Petrotos, K.; Lykas, C.; Khah, E. Chemical composition and yield of six genotypes of common purslane (Portulaca oleracea L.): An alternative source of omega-3 fatty acids. Plant Foods Hum. Nutr. 2015, 70, 420-426. [CrossRef]

34. Guoyin, Z.; Hao, P.; Min, L.; Wei, G.; Zhe, C.; Changquan, L. Antihepatocarcinoma Effect of Portulaca oleracea L. in Mice by PI3K/Akt/mTOR and Nrf2/HO-1/NF- к B Pathway. Evid. Based Complement. Altern. Med. 2017, 2017, 1-11. [CrossRef]

35. Eidi, A.; Mortazavi, P.; Moghadam, J.Z.; Mardani, P.M. Hepatoprotective effects of Portulaca oleracea extract against CCl 4 -induced damage in rats. Pharm. Biol. 2015, 53, 1042-1051. [CrossRef] [PubMed]

36. Egea-Gilabert, C.; Ruiz-Hernández, M.V.; Parra, M.Á.; Fernández, J.A. Characterization of purslane (Portulaca oleracea L.) accessions: Suitability as ready-to-eat product. Sci. Hortic. 2014, 172, 73-81. [CrossRef]

37. Gonnella, M.; National, I.; Charfeddine, M.; Agricultural, C.R.A.; Universit, G.C.; Universit, P.S.; Moro, B.A. Purslane: A review of its potential for health and agricultural aspects. Eur. J. Plant Sci. Biotechnol. 2010, 4, 131-136. 
38. Alvarado-Gómez, E.; Tapia, J.I.; Encinas, A. A sustainable hydrophobic luffa sponge for efficient removal of oils from water. Sustain. Mater. Technol. 2021, 28, e00273. [CrossRef]

39. Adewuyi, A.; Oderinde, R.A.; Rao, B.V.S.K.; Prasad, R.B.N.; Anjaneyulu, B. Blighia unijugata and Luffa cylindrica Seed Oils: Renewable Sources of Energy for Sustainable Development in Rural Africa. Bioenergy Res. 2012, 5, 713-718. [CrossRef]

40. Ali, M.A.; Azad, M.A.K.; Yeasmin, M.S.; Khan, A.M.; Sayeed, M.A. Oil characteristics and nutritional composition of the ridge gourd (Luffa acutangula Roxb.) seeds grown in Bangladesh. Food Sci. Technol. Int. 2009, 15, 243-250. [CrossRef]

41. Kamel, B.S.; Blackman, B. Nutritional and oil characteristics of the seeds of angled Luffa Luffa acutangula. Food Chem. 1982, 9 , 277-282. [CrossRef]

42. Muthumani, P.; Meera, R.; Mary, S.; Jeenamathew; Devi, P.; Kameswari, B.; Eswara Priya, B. Phytochemical screening and anti inflammatory, bronchodilator and antimicrobial activities of the seeds of Luffa cylindrica. Res. J. Pharm. Biol. Chem. Sci. 2010, 1, $11-22$.

43. Spréa, R.M.; Fernandes, Â.; Calhelha, R.C.; Pereira, C.; Pires, T.C.S.P.; Alves, M.J.; Canan, C.; Barros, L.; Amaral, J.S.; Ferreira, I.C.F.R. Chemical and bioactive characterization of the aromatic plant Levisticum officinale W.D.J. Koch: A comprehensive study. Food Funct. 2020, 11, 1292-1303. [CrossRef] [PubMed]

44. Abreu, R.M.V.; Ferreira, I.C.F.R.; Calhelha, R.C.; Lima, R.T.; Vasconcelos, M.H.; Adega, F.; Chaves, R.; Queiroz, M.J.R.P. Anti-hepatocellular carcinoma activity using human HepG2 cells and hepatotoxicity of 6-substituted methyl 3-aminothieno[3,2b]pyridine-2- carboxylate derivatives: In vitro evaluation, cell cycle analysis and QSAR studies. Eur. J. Med. Chem. 2011, 46, 5800-5806. [CrossRef] [PubMed]

45. Finimundy, T.C.; Karkanis, A.; Fernandes, Â.; Petropoulos, S.A.; Calhelha, R.; Petrović, J.; Soković, M.; Rosa, E.; Barros, L.; Ferreira, I.C.F.R. Bioactive properties of Sanguisorba minor L. cultivated in central Greece under different fertilization regimes. Food Chem. 2020, 327, 127043. [CrossRef]

46. Zamani Ghaleshahi, A.; Ezzatpanah, H.; Rajabzadeh, G.; Ghavami, M. Comparison and analysis characteristics of flax, perilla and basil seed oils cultivated in Iran. J. Food Sci. Technol. 2020, 57, 1258-1268. [CrossRef]

47. Ren, G.; Zhang, W.; Sun, S.; Duan, X.; Zhang, Z. Enhanced extraction of oil from flaxseed (Linum usitatissimum L.) using microwave pre-treatment. J. Oleo Sci. 2015, 64, 1043-1047. [CrossRef]

48. Gutte, K.B.; Sahoo, A.K.; Ranveer, R.C. Effect of ultrasonic treatment on extraction and fatty acid profile of flaxseed oil. OCL Oilseeds Fats 2015, 22. [CrossRef]

49. Liu, L.; Howe, P.; Zhou, Y.F.; Xu, Z.Q.; Hocart, C.; Zhang, R. Fatty acids and $\beta$-carotene in Australian purslane (Portulaca oleracea) varieties. J. Chromatogr. A 2000, 893, 207-213. [CrossRef]

50. Delfan-Hosseini, S.; Nayebzadeh, K.; Mirmoghtadaie, L.; Kavosi, M.; Hosseini, S.M. Effect of extraction process on composition, oxidative stability and rheological properties of purslane seed oil. Food Chem. 2017, 222, 61-66. [CrossRef] [PubMed]

51. Ionescu, M.; Voicu, G.; Sorin-Stefan, B.; Covaliu, C.; Dincă, M.; Ungureanu, N. Parameters influencing the screw pressing process of oilseed materials. In Proceedings of the 2nd International Conference on Thermal Equipment, Renewable Energy and Rural Development, Băile Olăneşti, Romania, 20-22 July 2013; pp. 243-248.

52. Nyam, K.L.; Tan, C.P.; Lai, O.M.; Long, K.; Che Man, Y.B. Physicochemical properties and bioactive compounds of selected seed oils. LWT Food Sci. Technol. 2009, 42, 1396-1403. [CrossRef]

53. Murkovic, M.; Hillebrand, A.; Winkler, J.; Leitner, E.; Pfannhauser, W. Variability of fatty acid content in pumpkin seeds (Cucurbita pepo L.). Eur. Food Res. Technol. 1996, 203, 216-219. [CrossRef] [PubMed]

54. García-Díaz, M.T.; Martínez-Rivas, J.M.; Mancha, M. Temperature and oxygen regulation of oleate desaturation in developing sunflower (Helianthus annuus) seeds. Physiol. Plant. 2002, 114, 13-20. [CrossRef]

55. Guil, J.L.; Torija, M.E.; Giménez, J.J.; Rodriguez, I. Identification of fatty acids in edible wild plants by gas chromatography. J. Chromatogr. A 1996, 719, 229-235. [CrossRef]

56. Petropoulos, S.A.; Fernandes, Â.; Dias, M.I.; Pereira, C.; Calhelha, R.C.; Chrysargyris, A.; Tzortzakis, N.; Ivanov, M.; Sokovic, M.D.; Barros, L.; et al. Chemical composition and plant growth of Centaurea raphanina subsp. mixta plants cultivated under saline conditions. Molecules 2020, 25, 2204. [CrossRef]

57. Petropoulos, S.; Fernandes, Â.; Karkanis, A.; Ntatsi, G.; Barros, L.; Ferreira, I. Successive harvesting affects yield, chemical composition and antioxidant activity of Cichorium spinosum L. Food Chem. 2017, 237, 83-90. [CrossRef]

58. Yoon, B.K.; Jackman, J.A.; Valle-González, E.R.; Cho, N.J. Antibacterial Free Fatty Acids and Monoglycerides: Biological Activities, Experimental Testing, and Therapeutic Applications. Int. J. Mol. Sci. 2018, 19, 1114. [CrossRef]

59. Dashora, N.; Chauhan, L.S.; Kumar, N. In vitro Cytotoxic Activity of Luffa acutangula on Human Neuronal Glioblastoma and Human Lung Adenocarcinoma Cell Lines. Sch. Acad. J. Pharm. 2014, 3, 401-405.

60. Vanajothi, R.; Sudha, A.; Manikandan, R.; Rameshthangam, P.; Srinivasan, P. Luffa acutangula and Lippia nodiflora leaf extract induces growth inhibitory effect through induction of apoptosis on human lung cancer cell line. Biomed. Prev. Nutr. 2012, 2, 287-293. [CrossRef]

61. Dashora, N.; Chauhan, L.S. Evaluation of antitumor potential of Luffa acutangula on Ehrlich's ascites carcinoma treated mice. Int. J. Pharm. Clin. Res. 2015, 7, 296-299.

62. Shendge, P.N.; Belemkar, S. Therapeutic potential of Luffa acutangula: A review on its traditional uses, phytochemistry, pharmacology and toxicological aspects. Front. Pharmacol. 2018, 9. [CrossRef] [PubMed] 
63. Mason, J.K.; Chen, J.; Thompson, L.U. Flaxseed oil-trastuzumab interaction in breast cancer. Food Chem. Toxicol. 2010, 48, 2223-2226. [CrossRef]

64. Sorice, A.; Guerriero, E.; Volpe, M.G.; Capone, F.; La Cara, F.; Ciliberto, G.; Colonna, G.; Costantini, S.; McPhee, D.J. Differential response of two human breast cancer cell lines to the phenolic extract from flaxseed oil. Molecules 2016, 21, 319. [CrossRef]

65. Truan, J.S.; Chen, J.M.; Thompson, L.U. Flaxseed oil reduces the growth of human breast tumors (MCF-7) at high levels of circulating estrogen. Mol. Nutr. Food Res. 2010, 54, 1414-1421. [CrossRef] [PubMed]

66. Medjakovic, S.; Hobiger, S.; Ardjomand-woelkart, K.; Bucar, F.; Jungbauer, A. Pumpkin seed extract: Cell growth inhibition of hyperplastic and cancer cells, independent of steroid hormone receptors. Fitoterapia 2016, 110, 150-156. [CrossRef]

67. Chari, K.Y.; Polu, P.R.; Shenoy, R.R. An Appraisal of Pumpkin Seed Extract in 1, 2-Dimethylhydrazine Induced Colon Cancer in Wistar Rats. J. Toxicol. 2018, 2018. [CrossRef]

68. Abou-Elella, F.; Mourad, R. Anticancer and anti-oxidant potentials of ethanolic extracts of Phoenix dactylifera, Musa acuminata and Cucurbita maxima. Res. J. Pharm. Biol. Chem. Sci. 2015, 6, 710-720.

69. Colagar, A.H.; Souraki, O.A. Review of Pumpkin Anticancer Effects. Quran Med. 2011, 1, 77-88. [CrossRef]

70. Heng, C.X.; Li, F.; Li, Z.; Zhang, Z.C. Purification and characterization of Moschatin, a novel type I ribosome-inactivating protein from the mature seeds of pumpkin (Cucurbita moschata), and preparation of its immunotoxin against human melanoma cells. Cell Res. 2003, 13, 369-374. [CrossRef]

71. Khan, N.; Jajeh, F.; Khan, M.I.; Mukhtar, E.; Shabana, S.M.; Mukhtar, H. Sestrin-3 modulation is essential for therapeutic efficacy of cucurbitacin B in lung cancer cells. Carcinogenesis 2017, 38, 184-195. [CrossRef]

72. Bardaa, S.; Halima, N.B.; Aloui, F.; Mansour, R.B.; Jabeur, H.; Bouaziz, M. Oil from pumpkin (Cucurbita pepo L.) seeds: Evaluation of its functional properties on wound healing in rats. Lipids Health Dis. 2016, 15, 1-12. [CrossRef]

73. Al-Okbi, S.Y.; Mohamed, D.A.; Kandil, E.; Ahmed, E.K.; Mohammed, S.E. Antioxidant and anti-cancer effect of Egyptian and European pumpkin seed oil. Res. J. Pharm. Biol. Chem. Sci. 2016, 7, 574-580.

74. Silva, R.; Carvalho, I.S. In vitro antioxidant activity, phenolic compounds and protective effect against DNA damage provided by leaves, stems and flowers of Portulaca oleracea (Purslane). Nat. Prod. Commun. 2014, 9, 45-50. [CrossRef] [PubMed]

75. Tian, J.L.; Liang, X.; Gao, P.Y.; Li, D.Q.; Sun, Q.; Li, L.Z.; Song, S.J. Two new alkaloids from Portulaca oleracea and their cytotoxic activities. J. Asian Nat. Prod. Res. 2014, 16, 259-264. [CrossRef]

76. Al-Sheddi, E.S.; Farshori, N.N.; Al-Oqail, M.M.; Musarrat, J.; Al-Khedhairy, A.A.; Siddiqui, M.A. Portulaca oleracea seed oil exerts cytotoxic effects on human liver cancer (HepG2) and human lung cancer (A-549) cell lines. Asian Pac. J. Cancer Prev. 2015, 16, 3383-3387. [CrossRef]

77. Al-Mathkhury, H.J.F.; Al-Dhamin, A.S.; Al-Taie, K.L. Antibacterial and Antibiofilm Activity of Flaxseed Oil. Iraqi J. Sci. 2016, 57, 1086-1095.

78. Kaithwas, G.; Mukerjee, A.; Kumar, P.; Majumdar, D.K. Linum usitatissimum (linseed/flaxseed) fixed oil: Antimicrobial activity and efficacy in bovine mastitis. Inflammopharmacology 2011, 19, 45-52. [CrossRef] [PubMed]

79. Santos, J.S.; Escher, G.B.; da Silva Pereira, J.M.; Marinho, M.T.; Prado-Silva, L.d.; Sant'Ana, A.S.; Dutra, L.M.; Barison, A.; Granato, D. $1 \mathrm{H}$ NMR combined with chemometrics tools for rapid characterization of edible oils and their biological properties. Ind. Crops Prod. 2018, 116, 191-200. [CrossRef]

80. Joshi, Y.; Garg, R.; Juyal, D. Evaluation of synergistic antimicrobial activity of Gemifloxacin with Linum usitatissimum seed oil. J. Phytopharm. 2014, 3, 384-388.

81. Swain, T.; Sahoo, R.K.; Kar, D.M.; Subudhi, E. Phytomedicinal potential of Luffa cylindrica (L.) Reom extracts. J. Pure Appl. Microbiol. 2013, 7, 697-703.

82. Ercisli, S.; Coruh, I.; Gormez, A.; Sengul, M. Antioxidant and antibacterial activities of Portulaca oleracea L. grown wild in Turkey. Ital. J. Food Sci. 2008, 20, 533-542.

83. Oraibi, A.; AlShammari, A.; Mohsien, R.; Obaid, W. Investigation the Antibacterial Activity of Portulaca oleracea L. Tissue Cultures in vitro. J. Pharm. Res. Int. 2017, 18, 1-7. [CrossRef]

84. Rahimi, V.B.; Ajam, F.; Rakhshandeh, H.; Askari, V.R. A pharmacological review on Portulaca oleracea L.: Focusing on antiinflammatory, anti- oxidant, immuno-modulatory and antitumor activities. J. Pharmacopunct. 2019, 22, 7-15. [CrossRef]

85. Du, Y.K.; Liu, J.; Li, X.M.; Pan, F.F.; Wen, Z.G.; Zhang, T.C.; Yang, P.L. Flavonoids extract from Portulaca oleracea L. induce Staphylococcus aureus death by apoptosis-like pathway. Int. J. Food Prop. 2017, 20, S534-S542. [CrossRef]

86. Tayel, A.A.; Shaban, S.M.; Moussa, S.H.; Elguindy, N.M.; Diab, A.M.; Mazrou, K.E.; Ghanem, R.A.; El-Sabbagh, S.M. Bioactivity and application of plant seeds' extracts to fight resistant strains of Staphylococcus aureus. Ann. Agric. Sci. 2018, 63, 47-53. [CrossRef]

87. Bakkiyaraj, S.; Pandiyaraj, S. Evaluation of potential antimicrobial activity of some medicinal plants against common food-borne pathogenic microorganism. Int. J. Pharma Bio Sci. 2011, 2, 484-491.

88. Othman, A.S. Bactericidal efficacy of omega-3 fatty acids and esters present in moringa oleifera and Portulaca oleracea fixed oils against oral and gastro enteric bacteria. Int. J. Pharmacol. 2017, 13, 44-53. [CrossRef]

89. Hammer, K.A.; Carson, C.F.; Riley, T. V Antimicrobial activity of essential oils and other plant extracts. J. Appl. Microbiol. 1999, 86, 985-990. [CrossRef] [PubMed]

90. Xuan, T.D.; Gangqiang, G.; Minh, T.N.; Quy, T.N.; Khanh, T.D. An overview of chemical profiles, antioxidant and antimicrobial activities of commercial vegetable edible oils marketed in Japan. Foods 2018, 7, 21. [CrossRef] 
91. Yang, R.; Wang, S.; Zhang, L.; Wang, X.; Ma, F.; Mao, J.; Zhang, Q. Evaluation and comparison of antibacterial activities of edible vegetable oils in China. Oil Crop Sci. 2018, 3, 57-62. [CrossRef]

92. Abdelillah, A.; Houcine, B.; Halima, D.; Meriel, C.S.; Imane, Z.; Eddine, S.D.; Abdallah, M.; Daoudi, C.S. Evaluation of antifungal activity of free fatty acids methyl esters fraction isolated from Algerian Linum usitatissimum L. seeds against toxigenic Aspergillus. Asian Pac. J. Trop. Biomed. 2013, 3, 443-448. [CrossRef]

93. Amrithaa, B.; Geetha, R.V. Comparative evaluation of antimycotic activity of Cucurbita maxima seed oil and orange peel oil in reducing Candida albicans count. Drug Invent. Today 2020, 14, 1210-1213.

94. Abd El-Aziz, A.B.; Abd El-Kalek, H.H. Antimicrobial proteins and oil seeds from pumpkin (Cucurbita moschata). Nat. Sci. 2011, 9, 105-119.

95. Sener, B.; Orhan, I.; Ozcelik, B.; Kartal, M.; Aslan, S.; Ozbilen, G. Antimicrobial and Antiviral Activities of Two Seed Oil. Nat. Prod. Commun. 2007, 2, 395-398. 